PROBLEMS

OF EDUCATION IN THE $21^{\text {st }}$ CENTURY Vol. 77, No. 6, 2019

IMPROVING THE SELF-AWARENESS CAPACITY OF SECONDARY SCHOOL STUDENTS BY FORMING A SCHOOL COUNSELING MODEL BASED ON STUDENT CAPACITY DEVELOPMENT ORIENTATION

\section{IN VIETNAM}

Luong Tran

Can Tho University, Vietnam E-mail: tluong@ctu.edu.vn

Son Van Huynh Ho Chi Minh City University of Education, Vietnam E-mail: sonhv@hcmue.edu.vn

Hoi Duc Dinh

Thai Nguyen University, Vietnam E-mail: dinhduchoi@dhsptn.edu.vn

Vu Thien Giang Ho Chi Minh City University of Education, Vietnam E-mail: thienvust0708@gmail.com

\begin{abstract}
The self-awareness capacity has long been no stranger in the foreign education, but in Vietnam, selfawareness capacity has only been developed in education in recent years. The self-awareness capacity related problems among Vietnamese students have been exacerbated such as gender-based violence, gender bias, wrong career choices, disorientation and school counseling activities currently could not support this difficulty for students. Based on the theoretical framework of self-awareness capacity from previous studies in Vietnam and further developing the aspects of self-awareness by age, the questionnaire had been done to survey of 726 lower-secondary school students and 474 upper-secondary school students to find the situation of their self-awareness capacity problems, as well as the need for self-awareness capacity problems counseling. The results demonstrated a positive correlation between self-awareness capacity problems and students'need for self-awareness capacity problems counseling. In addition, identifying self-awareness capacity problems encountered by students helps us to develop a new school counseling model, as well as a process to counsel self-awareness capacity problems for students to enhance the self-awareness capacity and support school counseling activities effectively, also meeting the requirements of renewing the general curriculum in the students' capacity development orientation in Vietnam.

Keywords: self-awareness, self-awareness capacity, school counseling model, school counseling activities, student capacity development orientation.
\end{abstract}


Luong TRAN, Son Van HUYNH, Hoi Duc DINH, Vu Thien GIANG. Improving the self-awareness capacity of secondary school students by forming a school counseling model based on student capacity development orientation in Vietnam

\section{Introduction}

PROBLEMS

OF EDUCATION

IN THE $21^{\text {st }}$ CENTURY

Vol. 77, No. 6, 2019

723

Vietnam is in the process of renewing the general education program towards the development of comprehensive student competencies (MOET, 2018). The capabilities that the Vietnamese education program aims to be researched and implemented on the basis of 5 competencies of social emotional learning (SEL) model, which have been very successful in many developed education programs around the world (Bierman \& Motamedi, 2015; Peterson, Gaskill, \& Cordova, 2018; Zins, 2004). One of the key competencies that the Vietnamese education program has been working towards is to enhance students' self-awareness capacity (SAC) through the content of subjects and educational activities in schools, including school counseling (SC) activities (MOET, 2018).

According to Huynh's study (2017) on the SAC of Vietnamese primary students when applying SEL education model (1004 participants), the SAC's mean was 2.45 - belonging to the above average level, demonstrated that Vietnamese primary students were fairly well aware of themselves. However, in Nguyen's study (2019) on secondary students' SAC when applying the SEL education model (509 participants), the mean decreased to 2.40 - still at above average level, but significantly lower than primary students' SAC with $p=.001$ (Son, 2018). The previous research had shown whether the SAC of Vietnamese students would continue to decline as they enter secondary school.

For students at secondary school levels, their self-awareness (SA) was an uninterrupted and important activity affecting human character formation and development (Nguyen, 2000). In each period of life, humans had had the tendency to judge himself or herself differently and express externally that SA orientation (Truong, 2003). During lower-secondary school time, students started an adult life, with the beginning of puberty period, they preferred to talk with friends rather to parents and tended to decide everything by themselves. In addition, they desired to be free from parents' care, protection and needed to be recognized as an adult (Huynh, 2011b). SA at this age was shown mainly by the need for being recognized as an adult (Tran, 2009). For students at upper-secondary school, they had more life experiences with a more objective viewpoint of the world, they thought in a more mature manner and gradually built up their own egos (Nguyen, 2009). They knew how to protect their own viewpoints, how to take care of themselves and how to express this externally. Their SA at this age achieved substantially stable development (Tran, 2014). Nevertheless, human's psychological development sometimes does not develop in a smooth way. Students often had arguments with parents, teachers, even friends in topics like personal viewpoints, lifestyle, clothing style and communication. They wanted to be themselves but had never been themselves (Tran, 2009). Many students became confused and unaware of themselves, gender and even future occupation (Nguyen, 2012). They faced a lot of problems in identifying hobbies, potential strongpoints and weaknesses, talents and capacities that they should have (Trang, 2007).

In developed countries, the education curriculum to enhance the SAC is always invested and becomes an indispensable feature of the educational program (Grossbard, 1954; Roeser \& Peck, 2009; Perez, 2011). But in Vietnam, SA has only been interested and integrated into learning content for about 5 years - when the achievements of SEL education model have been transferred into Vietnam (Son, 2019). Therefore, problems related to SA and SAC of Vietnamese students, especially in secondary school age (including lower-secondary and uppersecondary school education), are always a "top-trend" topic of many scientists. Some typical studies in Vietnam on this issue were: self-esteem of high school students showing depression expressions (Nguyen, 2000); self-image of students experiencing academic stress (Tran, 2013); the ego of Vietnamese pedagogy undergraduate students (Nguyen, 2007); the phenomenon of "illusion of strength" of high school students (Huynh, 2012); self-awareness and gender issues of high school students (Son, Tu, Vu, \& Hanh, 2019). These previous findings all pointed 
Luong TRAN, Son Van HUYNH, Hoi Duc DINH, Vu Thien GIANG. Improving the self-awareness capacity of secondary school students by forming a school counseling model based on student capacity development orientation in Vietnam

PROBLEMS

OF EDUCATION

IN THE $21^{\text {st }}$ CENTURY

Vol. 77, No. 6, 2019

724

to the importance of SC, as well as the counseling processes on the problems related to SA. However, up to now, Vietnam has not had a unified school counseling model (Son et al., 2019), including counseling processes specifically for those who have difficulties in SA. Therefore, it was necessary that school counselors should organize talks, sharing conference and personal counseling activities so that students could themselves sketch their future life prospect, put an effort in building it and have a better SAC.

Facing this reality, it should be directly to confirm that the current SC activities as well as SC model in Vietnam do not meet the students' need of counseling. Moreover, it could be a debate that the SAC problems and the need for counseling on SAC problems (NCSAC) of secondary students (SS) might have the correlation with each other and this correlation could be led to the effectiveness of SC activities in Vietnam. Therefore, by renovating the Vietnamese general education curriculum oriented to the capacity development of students, the purpose of this research was to conduct on the correlation between SAC problems and the NCSAC of SS to demonstrate the urgency of forming a new SC model supported by SAC problems for Vietnamese SS.

\section{Research Methodology}

\section{General Background}

In this research, the content of SAC-related problems of Vietnamese students were inherited from SEL's research by authors Huynh (2017), Van Huynh, Tran-Chi and Nguyen (2018), Son (2019) and Nguyen (2019). Findings from these studies had shown that one of the factors affecting SAC of Vietnamese students was the impact of culture and educational programs. Vietnam is a matriarchal country, village culture and the influence of families always strongly influence the psychological characteristics, as well as the child's SAC. Children must strictly follow family rules, as well as absolute obedience to what parents taught and guided. It was these outdated Confucian educational ideas that were deeply ingrained in the unconsciousness of Vietnamese. Thereby affecting the SAC of Vietnamese students today, they found it difficult to realize their strength/weakness, as well as a correct appreciation of the social position in their family and community. Their life goals seemed to be tightly restrained by the wishes of their parents and since then, many negative social problems have arisen. Therefore, the problems related to SAC of Vietnamese SS conducted in this study were:

- Recognizing personal strengths/ weaknesses (P1)

- Being fully aware of personal character/capacity (P2)

- Understanding personal aims/life ideals (P3)

- Identifying personal social status (P4)

- Knowing personal negative habits for change (P5)

\section{Sample Selection}

All participants were provided informed consent after receiving an explanation of the purpose of the research. Secondary school education in Vietnam is divided into 2 levels: lower-secondary level (from grade 6 to grade 9) and upper-secondary level (from grade 10 to grade 12) (Tran, 2010). Therefore, the participants were 1565 students randomly chosen from 4 lower-secondary schools and 3 upper-secondary schools in Vietnam, after removing unsatisfactory responses, the total number of participants was 1200 (see Table 1 for more participants' information). 
Luong TRAN, Son Van HUYNH, Hoi Duc DINH, Vu Thien GIANG. Improving the self-awareness capacity of secondary school students by forming a school counseling model based on student capacity development orientation in Vietnam

Table 1. General information of participants.

\begin{tabular}{|c|c|c|c|}
\hline Sources & & $F$ & $\%$ \\
\hline \multirow{2}{*}{ Gender } & Male & 449 & 37.4 \\
\hline & Female & 751 & 62.6 \\
\hline \multirow{2}{*}{$\begin{array}{l}\text { Education } \\
\text { level }\end{array}$} & Lower-secondary school (from grade 6 to 9) & 726 & 60.5 \\
\hline & Upper-secondary school (from grade 10 to 12) & 474 & 39.5 \\
\hline \multirow{7}{*}{ Grade } & Grade 6 & 68 & 5.7 \\
\hline & Grade 7 & 9 & 0.8 \\
\hline & Grade 8 & 325 & 27.1 \\
\hline & Grade 9 & 324 & 27.0 \\
\hline & Grade 10 & 69 & 5.8 \\
\hline & Grade 11 & 246 & 20.5 \\
\hline & Grade 12 & 159 & 13.3 \\
\hline \multirow{4}{*}{$\begin{array}{l}\text { Living } \\
\text { condition } \\
\text { (Family } \\
\text { status) }\end{array}$} & With both parents & 1026 & 85.5 \\
\hline & With father (single-father family) & 35 & 2.9 \\
\hline & With mother (single-mother family) & 52 & 4.3 \\
\hline & With grandparents, uncle, aunt, relatives & 87 & 7.3 \\
\hline
\end{tabular}

\section{Instrument and Procedures}

With 5 main problems related to SAC, a questionnaire of the situation of SS' selfawareness and their need to be counseled on these problems was conducted. The questionnaire was designed in 2 steps: step 1 - rough survey with 15 open questions about SAC problems $(8$ items) and the need to counsel about SAC problems ( 7 items), the reliability of the questionnaire is 0.848 ; step 2 - designing an official questionnaire with 10 items (eliminating 5 items that did not match the developmental psychological characteristics of SS), in which, 5 items related to SAC problems and 5 related items to the NCSAC. Besides, the questionnaire also included the Introduction of research objectives and instruction on questionnaire responses, and the Information of participants: gender, year of birth, school level, grade, living condition.

\section{Data Analysis}

The questionnaire results were coded based on 5 level (5-point Likert scale) as below (see Table 2).

Table 2. Mean score encoding.

\begin{tabular}{lll}
\hline Mean & Coded & Level \\
\hline 1 to 1.80 & Totally none/ Totally unnecessary & 1 \\
1.81 to 2.61 & Under average/ Unnecessary & 2 \\
2.62 to 3.42 & Average/ Optional & 3 \\
3.43 to 4.23 & Rather difficult/ Necessary & 4 \\
4.24 to 5 & Very difficult Totally necessary & 5 \\
\hline
\end{tabular}


Luong TRAN, Son Van HUYNH, Hoi Duc DINH, Vu Thien GIANG. Improving the self-awareness capacity of secondary school students by forming a school counseling model based on student capacity development orientation in Vietnam

PROBLEMS

OF EDUCATION

IN THE $21^{\text {st }}$ CENTURY

Vol. 77, No. 6, 2019

The results were shown and descriptively analyzed in the mean $(\mathrm{M})$, the percentage (\%) and the ranking $(\mathrm{R})$ of the 5 main problems. A code example is $\mathrm{M}_{\mathrm{SAC}}$, which would denote the mean of self-awareness capacity problems. Besides, the level of the SAC problems and the NCSAC of SS were coded in the descriptive statistic table as $\mathrm{SAC}_{1}$, which meant the SS had totally none of self-awareness capacity problems (level 1 - totally none), or $\mathrm{NCSAC}_{5}$, which meant the need for counseling on self-awareness capacity problems of SS was totally necessary (level 5 - totally necessary). The other abbreviations mentioned in the table were coded as above examples. By analyzing the correlation (ANOVA and Pearson Correlation tests) between SAC problems and SS' needs for SAC counseling, the reliability of the results was verified.

\section{Research Results}

After surveying the participants, the situation of SAC of Vietnamese SS was found as in Table 3 below:

Table 3. Students' SAC problems and the need for SAC counseling.

\begin{tabular}{|c|c|c|c|c|c|c|c|c|c|c|c|c|c|c|c|c|}
\hline \multirow{2}{*}{ Items } & \multicolumn{11}{|c|}{ Levels } & \multicolumn{2}{|l|}{$M$} & \multicolumn{2}{|l|}{$S D$} & Rank \\
\hline & SAC & $\mathrm{NCSAC}_{1}$ & $\mathrm{SAC}_{2}$ & $\mathrm{NCSAC}_{2}$ & $\mathrm{SAC}_{3}$ & $\mathrm{NCSAC}_{3}$ & $\mathrm{SAC}_{4}$ & ${ }_{4} \mathrm{NCSAC}_{4}$ & $\mathrm{SAC}_{5}$ & $\mathrm{NCSAC}_{5}$ & $M_{S A C}$ & $\mathrm{M}_{\mathrm{NCSAC}}$ & $\mathrm{SD}_{\mathrm{SAC}}$ & $\mathrm{SD}_{\mathrm{NCSAC}}$ & $R_{S A C}$ & $\mathrm{R}_{\mathrm{NCSAC}}$ \\
\hline \multirow[t]{3}{*}{ P1 } & 310 & 211 & 202 & 164 & 469 & 242 & 112 & 310 & 107 & 273 & \multirow{2}{*}{2.59} & \multirow[t]{2}{*}{3.22} & \multirow{2}{*}{1.217} & \multirow{2}{*}{1.400} & \multirow[t]{2}{*}{2} & \multirow[t]{2}{*}{2} \\
\hline & 1025.8 & 17.6 & 16.8 & 13.7 & 39.1 & 20.2 & 9.3 & 25.8 & 8.9 & 22.8 & & & & & & \\
\hline & N 327 & 160 & 204 & 176 & 422 & 285 & 105 & 311 & 142 & 268 & \multirow[b]{2}{*}{2.61} & \multirow[b]{2}{*}{3.29} & \multirow[b]{2}{*}{1.292} & \multirow[b]{2}{*}{1.322} & \multirow[b]{2}{*}{1} & \multirow[b]{2}{*}{1} \\
\hline P2 & \% 27.3 & 13.3 & 17.0 & 14.7 & 35.2 & 23.8 & 8.8 & 25.9 & 11.8 & 22.3 & & & & & & \\
\hline \multirow[b]{2}{*}{ P3 } & V 322 & 202 & 213 & 121 & 419 & 283 & 134 & 311 & 112 & 283 & \multirow[b]{2}{*}{2.58} & \multirow[b]{2}{*}{3.29} & \multirow[b]{2}{*}{1.251} & \multirow[b]{2}{*}{1.376} & \multirow[b]{2}{*}{3} & \multirow[b]{2}{*}{1} \\
\hline & 10 26.8 & 16.8 & 17.8 & 10.1 & 34.9 & 23.6 & 11.2 & 25.9 & 9.3 & 23.6 & & & & & & \\
\hline \multirow{2}{*}{ P4 } & 380 & 251 & 198 & 172 & 405 & 278 & 147 & 297 & 70 & 202 & \multirow{2}{*}{2.44} & \multirow{2}{*}{3.02} & \multirow{2}{*}{1.215} & \multirow{2}{*}{1.379} & \multirow{2}{*}{4} & \multirow{2}{*}{4} \\
\hline & \% 31.7 & 20.9 & 16.5 & 14.3 & 33.8 & 23.2 & 12.3 & 24.8 & 5.8 & 16.8 & & & & & & \\
\hline \multirow{2}{*}{ P5 } & 307 & 222 & 310 & 176 & 405 & 264 & 114 & 278 & 64 & 260 & 213 & 315 & 1126 & 1402 & 5 & 3 \\
\hline & \% 25.6 & 18.5 & 25.8 & 14.7 & 33.8 & 22.0 & 9.5 & 23.2 & 5.3 & 21.7 & & & & & & \\
\hline$\overline{M_{x}}$ & & & & & & & & & & & 2.53 & 3.20 & 1.071 & 1.221 & & \\
\hline
\end{tabular}

$\mathrm{M}_{\mathrm{X}-\mathrm{SAC}}=2.53$, evaluated as 'below average'. Of all the 5 items, only one item reaches the 'moderate' level: students specifically had difficulty in being fully aware of personal character/ capacity whereas other behaviors are below average points.

$\mathrm{M}_{\mathrm{X} \text {-NCSAC}}=3.20$, evaluated as optional level. This result showed that SS only needed SAC problems counseling when they were in troubles, but sometimes they chose to keep for themselves and did not want to be counseled.

The differences in the needs of SAC counseling as well as the SAC problems in students with different gender, school level and living conditions were shown in Table 4. 
Luong TRAN, Son Van HUYNH, Hoi Duc DINH, Vu Thien GIANG. Improving the self-awareness capacity of secondary school students by forming a school counseling model based on student capacity development orientation in Vietnam

Table 4. Verifying the differences among gender, school level and living condition related to students' SAC problems and the NCSAC.

\begin{tabular}{|c|c|c|c|c|c|c|c|}
\hline \multirow{2}{*}{ Sources } & & \multicolumn{2}{|l|}{$M$} & \multicolumn{2}{|c|}{ ANOVA test } & \multicolumn{2}{|l|}{$S D$} \\
\hline & & $M_{S A C}$ & $M_{\text {NCSAC }}$ & $p_{S A C}$ & $p_{\text {NCSAC }}$ & $S D_{S A C}$ & $S D_{\text {NCSAC }}$ \\
\hline \multirow{2}{*}{ Gender } & Male & 2.42 & 3.09 & \multirow[b]{2}{*}{-.416} & \multirow[b]{2}{*}{.023} & \multirow{5}{*}{1.071} & \multirow{5}{*}{1.221} \\
\hline & Female & 2.68 & 3.25 & & & & \\
\hline \multirow{2}{*}{$\begin{array}{l}\text { Education } \\
\text { Level }\end{array}$} & Lower-secondary school & 2.68 & 3.42 & \multirow{2}{*}{-.001} & \multirow{2}{*}{.001} & & \\
\hline & Upper-secondary school & | 2.42 & 3.04 & & & & \\
\hline Living condition & $\begin{array}{l}\text { Both father and mother } \\
\text { Father } \\
\text { Mother } \\
\text { Relatives/Others }\end{array}$ & $\begin{array}{l}2.56 \\
1.86 \\
2.60 \\
2.38 \\
\end{array}$ & $\begin{array}{l}3.15 \\
4.16 \\
3.53 \\
3.05 \\
\end{array}$ & -.001 & .001 & & \\
\hline
\end{tabular}

Regarding gender, $p_{\mathrm{SAC}}=.416$ affirmed no significant difference between boys and girls. Regarding education level, $p_{\mathrm{SAC}}=.001$ affirmed a significant difference between secondary and high school level. High school students faced more SAC than secondary students. Regarding living condition, $p_{\mathrm{SAC}}=.001$ affirmed a significant difference among students with different living conditions.

All indicators had $p_{\mathrm{NCSAC}}<.05$, affirmed a significant difference in SAC counseling need of SS based on gender, education level and living condition.

By using Pearson Correlation Test, the correlation between the SAC problems and the need of SAC counseling of Vietnamese SS was found in Table 5:

Table 5. Correlation coefficient between the SAC problems and the NCSAC.

\begin{tabular}{lll}
\hline & SAC problems & NCSAC \\
\hline SAC problems & 1 & $.631^{* *}$ \\
NCSAC & $.631^{* *}$ & 1 \\
\hline${ }^{* *}$. Correlation is significant at the .01 level (2-tailed). & & \\
\hline
\end{tabular}

The result with $p<.01$ affirmed a significant difference between the SAC and students' SAC counseling need.

\section{Discussion}

According to Jaleel (2016) in lower-secondary students' SAC, students always desired to discover personal capacities and characters so as to find the differences among themselves and others. They needed to prove to others that they have grown up and have been mature enough to solve real-life challenges. The thought of desiring to become adults and motivation for discovering themselves attracted a lot of researchers because they considered these as permanent teenager' activities, listing Duong (2008), Huynh (2011b), Nguyen et al. (2016). Comparing the previous findings, the result found in this research was the same. With regard to other behaviors of SA, some students also showed their concern, but this was not their priority need in their self-discovery at this age (Huynh, 2011a). Nevertheless, the results in Table 3 showed a substantial percentage of students facing lots of difficulties in their SAC at this age. This made sense for the progression of human development to experience ups and downs; hence, there should be gaps or scrolls or even regression (Phan, 2011). This could be called as puberty crisis (Huynh, 2011b) or changes coming from their own living or study environment. These impacts caused the condition of get off track and some students faced difficulties in 
Luong TRAN, Son Van HUYNH, Hoi Duc DINH, Vu Thien GIANG. Improving the self-awareness capacity of secondary school students by forming a school counseling model based on student capacity development orientation in Vietnam

PROBLEMS

OF EDUCATION IN THE $21^{\text {st }}$ CENTURY Vol. 77, No. 6, 2019

728

their SAC. This feature was extremely important to SS; therefore, it would be recommended that school counselors should be more conscious and better prepared for appropriate plans and filtering methods so as to more effectively and efficiently assist those students in this special group. Besides, even though the need of SAC counseling is at optional level, the results in Table 5 showed a substantial percentage of students with urgent needs of SAC counseling, mostly beyond $20 \%$, accounting for one-fifth at very necessary level among the 5 problems.

At a deeper analysis, SA is one completely decisive capacity for every human being: (1) At kindergarten level, children learn how to distinguish his/her gender - knowing who he/she is; (2) At primary level, students learn to understand more about his/her human body, begin to discover his/her gender activities as well as is used to self-evaluation; (3) At lower-secondary level, as the turning-point of puberty period, students are turning into grown-ups with clearer SAC: they know what they want to do, what they like to do; on the other hand, they have the desire to prove themselves and gradually separate themselves from parental protection; (4) At upper-secondary level, their SAC is further enhanced when they once again reaffirm their personal life values: they have the right to express their viewpoints, they almost escape their childhood period and are in the progress to become grown-ups (Nguyen et al., 2016). During each age period, one human being' needs of SA are different, generally speaking, these needs have advanced as time passes by. Lower-secondary and upper-secondary levels are the two periods that students must be aware fully of themselves especially in their gender identification period (Freud, quoted in Phan, 2011) and their life specification aim (Erikson, quoted in Phan, 2011). Therefore, the SAC counseling needs during the lower-secondary and upper-secondary levels have been absolutely compulsory. This content must be included in the new SC model that Vietnam is preparing to deploy. With subsequent studies, the proposed process of counseling on SAC when forming a SC model could also be a promising study in Vietnam.

With the indicators of gender, education level and living condition, some findings were discovered that needed to be considered when developing a SC model which was oriented towards student capacity development, as well as supporting SAC related problems.

Equivalently to White, Moeller, Ivcevic and Brackett (2018) research in gender identification and gender expression of 19,385 students in America. Their research revealed that there existed no difference in personal SA through 4 indicators (biological sex, gender identity, gender expression, sexual orientation) during students' self-labeling or being-labeled. Therefore, the problems related to students' SA are independent of gender indicator. However, the result showed that girls had a higher SAC need of counseling than boys. Different genders resulted in different counseling needs of SAC. This result was similar to the research by Leland (2015) related to the counseling need of SA of SS participating in Mindfulness training course. This research presented that the number of girls outweighs that of boys as well as girls' posttraining-course success surpasses that of boys'. This could be concluded that selection and assistance tasks towards SS having SAC problems must be paid more attention to the gender indicator so as to achieve higher efficiency and to assure gender equality.

The higher education level students were in, the more SAC problems they faced. This issue should be explained because the need of SA and of self-judgement as well as other ego-related problems had changed a great deal since students approached the high school age, in which, lots of distinctive needs were still existing within this high school environment. According to Hamedani and Darling-Hammond (2015), in researching American upper secondary students' social emotion capacity, upper secondary students' SAC was lower than that of lower secondary ones. In Vietnam, despite the fact that there had been no official research on high school students' SAC, the comparison and contrast between secondary level students (Nguyen, 2019) and primary level students (Huynh, 2017) in the study of social-emotional capacity in Vietnam's current educational program showed that secondary students' SAC was more junior than that of primary ones' due to the heavy educational program at secondary level with a focus 
Luong TRAN, Son Van HUYNH, Hoi Duc DINH, Vu Thien GIANG. Improving the self-awareness capacity of secondary school students by forming a school counseling model based on student capacity development orientation in Vietnam

PROBLEMS

OF EDUCATION

IN THE $21^{\text {st }}$ CENTURY

Vol. 77, No. 6, 2019

on scientific knowledge while there was little time on training soft-skills, life-skills as well as other social emotion capacity. At high school level, the time spent on compulsory subjects in the upcoming graduation examination and university entrance examination was shorter and more stressful; consequently, their study task mostly became a pressure for each student. Furthermore, the period of transition from secondary to high school level as well as bodily changes during puberty period (Duong, 2008) affected high school students' SAC. Therefore, high school students' SAC could not be more senior than that of those from secondary level. This range led to the consequence that SS faced more SAC problems because this was the time that they had to set up their lifetime goals besides understanding their personal capacity and hobbies as well as define their personal core values (Pham, 2011). Besides, high school students' SAC counseling needs were higher than students from secondary level. Occupational orientation is the main activity for high school students (Huynh, 2011): in any progress of occupational orientation or orientational counseling activity, the initial step to be performed is to help students raise their personal capacity, hobby and character (Le, 2019). More than that, SS just overcame the examination into grade 10 based on regulations by Ministry of Education and Training (2019), in which, new changes in study environment, classmates and study schedule unintentionally became an invisible pressure and altered students' usual previous personal values (Nguyen, 2000), they were usually lost at living direction and had the high SAC counseling need (Tran, 2014). Different education levels led to different SAC counseling needs.

Nonoyama-Tarumi (2017), researched the impacts of single-parent families on children's study achievement and life in Japan, concluded that those children living in single-mother families were disadvantageous (more than 50\%) due to financial lack. For those children living in single-father families, the educational shortcoming was further explained by the lack of children educational resource, which was measured by discussions at home, home observation and participating in school activities. Children living in single-father families had fewer personal problems because they were assured with financial guarantee. They complained less about financial issue and had clearer career orientation obviously influenced by fathers; nevertheless, other problems (educational method, love, psychological support) were not so well-solved compared to those living in families with mothers. Consequently, students with different living conditions faced different SAC related problems besides one similarity in potential problems related to students' SAC living in single-father families. Besides, by using post hoc test, those living with both parents and relatives presented no significant difference. The other two groups implied the significant differences in SAC counseling need; especially, those living with singleparent family had very high counseling need. This could be explained as below: for singlefather families, the SAC counseling need was the highest because these students were almost influenced from father with masculine strength, decisiveness and ultimate decision-making in life (Hanna, 2015), even obeying fathers' force in future career choice or marriage decision or other important events in their life (Jeynes, 2015). This led to the fact that students were losing their private personal viewpoint and own ego, so it was hard for them to become 'an ideal self' (Rogers, 2017), consequently, the SAC counseling needs within these student groups were very high. Related to single-mother families, students were provided with full of maternal love, care and protection (Luthar \& Eisenberg, 2017); however, these students lacked decisiveness or determinedness characters from a father (Wong, 2017) as well as suffered unstable financial background (Härkönen, 2018); as a result, students living in single-mother families possessed a rather rough SAC and they were in need of support from SC activities.

This research had certain limitations. The SAC for a long time is no longer a problem in many foreign education programs around the world. However, in Vietnam, SAC has always been interested and invested in research to renovate the quality of education over the years. The issues of gender discrimination, wrong choice of career or the value crisis of many Vietnamese youths over the years have proved the need to implement SAC for students and also support 
Luong TRAN, Son Van HUYNH, Hoi Duc DINH, Vu Thien GIANG. Improving the self-awareness capacity of secondary school students by forming a school counseling model based on student capacity development orientation in Vietnam

PROBLEMS

OF EDUCATION

IN THE $21^{\text {st }}$ CENTURY Vol. 77, No. 6, 2019

730

them to have the right SA to themselves. Although the results only reflected the current situation, the number of items in the questionnaire was very small, but these were all questions and difficulties in SAC that Vietnamese students encountered in many past years. Therefore, these findings have a certain meaning and can be an important data source to form a process of SC on $\mathrm{SAC}$ problems for HS to develop their SAC or form a new SC model having this content in the counseling activities when Vietnam applies a new education program.

\section{Conclusions}

In result, Vietnamese HS were facing SAC problems and their SAC counseling needs mainly include: identifying personal strong-points/weak-points; knowing personal character/ capacity; understanding personal goal/life ideal; identifying personal position in social relationship; knowing negative habits that need to change. The more SAC students faced, the higher the counseling needs for SAC they had. Therefore, SAC counseling in SC activity must be enhanced to support students in becoming more aware of himself/herself and know how to adjust himself/herself to be suitable to life activities. This is also the content of HS counseling activities on SAC problems that should be concerned by international SC models, especially Asian countries with cultural similarities with Vietnam.

On the other hand, from the current situation of SC activity in Vietnam, it should be concluded that this activity has been performed with some limitation, SC activity could not totally prove its efficiency compared to the general demand of Vietnam educational program. Therefore, the Vietnamese school counselors should put more effort in strengthening their academic professional knowledge and applying continuously more detailed plans related to SC activity for a substantial change in quality and quantity features regarding to this SC program. Moreover, the forming of a new SC model to meet the capacity development requirements for students, including SAC, is an essential condition for renewing general educational programs that Vietnam is about to conduct.

\section{Acknowledgement}

This research project belonged to the ETEP program - Vietnam research mission in 2020

\section{References}

Bierman, K. L., \& Motamedi, M. (2015). Social and emotional learning programs for preschool children. In J. Durlak, C. Domitrovich, R. P. Weissberg, \& T. Gullotta (Eds.), The handbook of social and emotional learning: Research and practice (pp.135-50). New York, USA: Guilford.

Duong, T. D. H. (2008). Giáo trình Tâm lý học phát triển [Development psychology]. Hanoi, Vietnam: Hanoi Education University Publisher.

Eremie, M. D., \& Ezeoma, V. O. (2019). Investigation of guidance and counselling needs of students in senior secondary school in River State. International Journal of Innovative Development and Policy Studies, 7(1), 33-43.

Grossbard, H. (1954). Methodology for developing self-awareness. Social Casework, 35(9), 380-386. doi: https://doi.org/10.1177/104438945403500902.

Hamedani, M. G., \& Darling-Hammond, L. (2015). Social emotional learning in high school: How three urban high schools engage, educate, and empower youth. California, USA: Stanford Center for Opportunity Policy in Education.

Hanna, M. A. (2015). The effects of father involvement in adolescence on cortisol reactivity in young adulthood: The mediating role of perceived mattering (Unpublished Master thesis). Arizona State University, Arizona, USA. 
Luong TRAN, Son Van HUYNH, Hoi Duc DINH, Vu Thien GIANG. Improving the self-awareness capacity of secondary school students by forming a school counseling model based on student capacity development orientation in Vietnam

$\mid \begin{aligned} & \text { PROBLEMS } \\ & \text { OF EDUCATION } \\ & \text { IN THE } 21^{\text {st }} \text { CENTURY } \\ & \text { Vol. 77, No. 6, } 2019\end{aligned}$

Härkönen, J. (2018). Single-mother poverty: How much do educational differences in single motherhood matter. In Nieuwenhuis. R. \& Maldonado, L. C. (Eds.), The Triple bind of single-parent families (pp.31-50). Bristol, the UK: Policy Press.

Hoang, T. C. T. (2000). Các biểu hiện liên quan đến sức khoẻ tâm thần ở trẻ em và vị thành niên ở hai phuoòng dân cu thuộc Hà Nộ [Symptoms related to mental health among children and adolescents in two residential wards in Hanoi]. (Unpublished Master thesis). Hanoi Education University, Hanoi, Vietnam.

Huynh, M. T. (2007). Thục trạng hoạt động TVHĐ tại các truòng trung học ở nội thành Thành phố Hồ Chí Minh [Situation of school counseling activities at highschools in Ho Chi Minh City]. (Unpublished Master thesis). Ho Chi Minh City University of Education, Vietnam.

Huynh, V. S. (2011a). Tâm lý hoc đại cuoong [General Psychology]. Ho Chi Minh City, Vietnam: Ho Chi Minh City University of Education Publisher.

Huynh, V. S. (2011b). Nhập môn Tâm lý học phát triển [An introduction to Development Psychology]. Ho Chi Minh City, Vietnam: Vietnam Education Publisher.

Huynh, V. S. (2012). Hành vi nghiện duoói góc độ Tâm lý học [Addiction behavior from a psychological perspective]. Ho Chi Minh City, Vietnam: Vietnam Education Publisher.

Huynh, V. S. (2017). Applying SEL model into life-skill education for primary student (Unpublished NAFOSTED research, code: 501.01-2016.04). Ho Chi Minh City University of Education, Ho Chi Minh City, Vietnam.

Jaleel, S. (2016). A study on the metacognitive awareness of secondary school students. Universal Journal of Educational Research, 4(1), 165-172. doi: 10.13189/ujer.2016.040121.

Jeynes, W. H. (2015). A meta-analysis: The relationship between father involvement and student academic achievement. Urban Education, 50(4), 387-423. doi: 10.1177/0042085914525789.

Lasode, A. O., Lawal, O. O., \& Ofodile, M. C. (2017). Students' need for awareness, perception and use of guidance and counselling services in Federal University of Agriculture, Abeokuta, Nigeria. Problems of Education in the 21st Century, 75(2), 170-181.

Le, D. H. (2019). Nhu cầu của học sinh trung học phổ thông về người làm công tác tư vấn hướng nghiệp [High school students' needs for career counseling]. In Proceedings of the Conference on the situation of school counseling in high schools in Can Tho city, June 2019. Ho Chi Minh City: Ho Chi Minh City University of Education Publisher.

Leland, M. (2015). Mindfulness and student success. Journal of Adult Education, 44(1), 19-24.

Luthar, S. S., \& Eisenberg, N. (2017). Promoting Strengths and Resilience in Single-Mother Families. Child Development, 88(2), 350-358. doi: https://doi.org/10.1111/cdev.12741

Nguyen, N. B. (2000). Tâm lý học nhân cách [Personality psychology]. Hanoi, Vietnam: Hanoi National University.

Nguyen, Q. U. (2009). Tâm lý học đại cuoong [General Psychology]. Hanoi, Vietnam: Hanoi Education University Publisher.

Nguyen, T. N. (2012). Khảo sát nhu cầu tham vấn tâm lý của họ sinh trung học cơ sở huyện Bình Chánh TP.HCM [Survey on counseling needs of secondary school students in Binh Chanh district, Ho Chi Minh City] (Unpublished Master thesis). Ho Chi Minh City University of Education, Vietnam.

Nguyen, T. T. (2007). Ego is the totality of the multifaceted personality of adolescence. Unpublished conference proceeding of Collection: "The psychological perspective approach from many angles", Saint - Peterbuarg, Russia.

Nguyen, T. T. (2019). Applying SEL model into secondary education activities (Unpublished Ministrylevel research, code: B2017-SPS-10). Ho Chi Minh City University of Education, Ho Chi Minh City, Vietnam.

Nguyen, T. T., et al. (2016). Giáo trình Tâm lý học lứa tuổi và Tâm lý học su phạm [Age Psychology and Pedagogical Psychology]. Ho Chi Minh City, Vietnam: Ho Chi Minh City University of Education Publisher.

Nonoyama-Tarumi, Y. (2017). Educational achievement of children from single-mother and singlefather families: The case of Japan. Journal of Marriage and Family, 79(4), 915-931. https://doi. org/10.1111/jomf.12409.

Perez, L. M. (2011). Teaching emotional self-awareness through inquiry-based education. Early Childhood Research \& Practice, 13(2), 1-8. 
Luong TRAN, Son Van HUYNH, Hoi Duc DINH, Vu Thien GIANG. Improving the self-awareness capacity of secondary school students by forming a school counseling model based on student capacity development orientation in Vietnam

PROBLEMS

OF EDUCATION

IN THE $21^{\text {st }}$ CENTURY Vol. 77, No. 6, 2019

732

Peterson, A., Gaskill, M., \& Cordova, J. (2018, March). Connecting STEM with Social Emotional Learning (SEL) Curriculum in Elementary Education. In Society for Information Technology \& Teacher Education International Conference (pp. 1212-1219). Association for the Advancement of Computing in Education (AACE).

Pham, M. H. (2011). Đặc điểm tâm lý trong hoạt động chọn nghề của học sinh lớp 12 trung học phổ thông hiện nay [Psychological characteristics in career-selection activities of high school students today] (Unpublished doctor thesis). Social science and Humanity University - Hanoi National University, Vietnam.

Phan, T. N. (2011). Giáo trình Các li thuyết phát triển tâm lí người [Textbook: The theory of the development in human psychology]. Hanoi, Vietnam: Hanoi Education University.

Roeser, R. W., \& Peck, S. C. (2009). An education in awareness: Self, motivation, and self-regulated learning in contemplative perspective. Educational Psychologist, 44(2), 119-136. doi: https://doi. org/10.1080/00461520902832376.

Rogers, C. R. (2017). What it means to become a person. In Alan Hooper (Eds), Leadership Perspectives (pp. 297-314). London, England: Routledge.

Son, H. V. (2018). Social Awareness and Responsible Decision Making of Students in Grade 4 and 5 in Viet Nam. Journal of Education and Human development, 4(7), 7-15.

Son, H. V. (2019). Embedding Social Emotional Learning Core Content into Life-Skills Instruction for Vietnamese Primary Students. International Journal of Educational Sciences, 7(3), 1-7.

Son, H. V., Tu. N. T., Vu. G. T., \& Hanh, M. M. (2019). The correlation between gender problems and gender counseling's need of Vietnamese Students. International Journal of Medical Research \& Health Sciences, 8(8), 25-33.

Tran, K. D. (2010). Giáo dục và phát triển nguồn nhân lục trong thế kỷ XXI [Education and human resource development in the 21st century]. Hanoi, Vietnam: Vietnamese Education Publisher.

Tran, T. M. D. (2009). Giáo trình tham vấn tâm lý [Textbook: Counseling psychology]. Hanoi: Hanoi National Publisher.

Tran, T. M. D. (2014). Tham vấn học đương [School counseling]. Safe, friendly and equal school project. Hanoi, Vietnam: Plan Corp Publisher.

Tran, T. T. M. (2013). Self-management skills of pedagogical students. Journal of Psychology, 3(3), 5968.

Truong, B. B. (2003). Bước đầu tìm hiểu sụ cần thiết của công tác tu vấn học đường hiện nay tại một số truòng cấp 2 - 3 tại TP. Hồ Chi Minh [Initially learn the necessity of current school counseling at some secondary schools in Ho Chi Minh City] (Unpublished Undergraduate thesis). Ho Chi Minh City University of Education, Vietnam.

Van Huynh, S., Tran-Chi, V. L., \& Nguyen, T. T. (2018). Vietnamese teachers' perceptions of socialemotional learning education in primary schools. European Journal of Contemporary Education, 7(4), 874-881.

Vietnamese Ministry of Education and Training (MOET). (2018). Thông tu số 32/2018/TT-BGDĐT ngày 26 tháng 12 năm 2018 của Bộ trương Bộ Giáo dục và Đào tạo về Ban hành Chương trình Giáo dục phổ thông tổng thể [Circular No. 32/2018/TT-BGDDT dated December 26, 2018 of the Minister of Education and Training on Promulgating the Overall General Education Program]. Hanoi, Vietnam: Vietnamese Government Publishing Service.

White, A. E., Moeller, J., Ivcevic, Z., \& Brackett, M. A. (2018). Gender identity and sexual identity labels used by US high school students: A co-occurrence network analysis. Psychology of Sexual Orientation and Gender Diversity, 5(2), 243.

Wong, S. K. (2017). The effects of single-mother and single-father families on youth crime: examining five gender-related hypotheses. International Journal of Law, Crime and Justice, 50, 46-60.

Zins, J. E. (Ed.). (2004). Building academic success on social and emotional learning: What does the research say? New York, USA: Teachers College Publisher. 
Luong TRAN, Son Van HUYNH, Hoi Duc DINH, Vu Thien GIANG. Improving the self-awareness capacity of secondary school students by forming a school counseling model based on student capacity development orientation in Vietnam

PROBLEMS

OF EDUCATION

IN THE $21^{\text {st }}$ CENTURY

Vol. 77, No. 6, 2019

733

Received: September 01, 2019

Accepted: November 18, 2019

\begin{tabular}{|ll|}
\hline Luong Tran & $\begin{array}{l}\text { Doctor of Education, Head of Educational Psychology Department, Can Tho University, } \\
\text { area 2, Ba Thang Hai street, Xuan Khanh ward, Ninh Kieu district, Can Tho City, Vietnam. } \\
\text { E-mail: tluong@ctu.edu.vn }\end{array}$ \\
\hline Son Van Huynh & $\begin{array}{l}\text { Doctor of Psychology, Vice-rector, Ho Chi Minh City University of Education, 280A An } \\
\text { Duong Vuong street, ward 4, district 5, Vietnam. } \\
\text { E-mail: sonhv@hcmue.edu.vn }\end{array}$ \\
\hline Hoi Duc Dinh & $\begin{array}{l}\text { Doctor of Psychology, Assistant Dean of Early Childhood Education Department, Thai } \\
\text { Nguyen University, No.20, Luong Ngoc Quyen street, Thai Nguyen City, Thai Nguyen } \\
\text { Province, Vietnam. } \\
\text { E-mail: dinhduchoi@dhsptn.edu.vn }\end{array}$ \\
\hline $\begin{array}{l}\text { Vu Thien Giang } \\
\text { (Corresponding author) }\end{array}$ & $\begin{array}{l}\text { Bachelor of Psychology, PhD Student, Researcher, Psychology Department, Ho Chi Minh } \\
\text { City University of Education, 280AAn Duong Vuong street, ward 4, district 5, Vietnam. } \\
\text { E-mail: thienvust0708@gmail.com }\end{array}$
\end{tabular}

